\title{
Infestation by excavating sponges on the oyster (Ostrea edulis) populations of the Blanes littoral zone (north-western Mediterranean Sea)
}

\author{
Dolors Rosell*, Maria-Jesús Uriz and Daniel Martin \\ Centre d’Estudis Avançats de Blanes, Camí de Santa Bàrbara, s/n, 17300 Blanes, Girona, Spain. *E-mail: rosell@ceab.csic.es
}

\begin{abstract}
In order to estimate the degree of implantation of excavating sponges in the oyster populations from the littoral zone at Blanes (north-western Mediterranean Sea), a representative sample of oysters (Ostrea edulis) was collected from depths between 0.5 and $4 \mathrm{~m}$ in 1986. All oysters were infested by the excavating sponges Cliona viridis and Cliona celata. Infestation affected always and exclusively the lower valve always reaching the inner side. The degree of infestation proved to be independent of oyster size and weight. Colonization by contact was considered the main means of dispersion of these sponges within the oyster population. Cliona viridis and C. celata emerged as the single excavating species able to effectively compete with other non-excavating or excavating organisms when trying to colonize the particular calcareous substrate provided by oyster shells in the north-western Mediterranean Sea.
\end{abstract}

\section{INTRODUCTION}

The only calcareous substrate available for excavating sponges in granite coasts are mollusc shells, calcified algae, skeletons of corals and, occasionally, bryozoans and tubes of sedentary polychaetes. At the shallow depths (from 0.5 to $10 \mathrm{~m}$ ) of the north-western Mediterranean coasts, calcareous substrates are even less abundant than at the subjacent bottoms (down to $40 \mathrm{~m}$ depth). Most of the calcareous substrates at these shallow bottoms consist of concretions of the coraline algae Lithophyllum incrustans Philippi, which forms thin plates (between 0.5 and $1 \mathrm{~cm}$ thickness) over the granitic substrate. Due to the scarcity of available substrate to be colonized, oysters from these zones support a large amount of epibionts and endobionts, among which are included the excavating sponges. Surprisingly, shells of other molluscs similarly abundant at the same depths such as mussels (Mytilus edulis L.) and some gastropod species were not excavated by sponges.

From an economic point of view, sponges which excavate oyster shells are considered detrimental, particularly when the infested populations belong to commercial oyster farms (Korringa, 1951; Warburton, 1958; Thomas, 1979). From an ecological point of view, the infestation may cause considerable stress to natural oyster populations. The simple fact that excavating sponges attack and excavate galleries in the oyster shells should not necessarily pose a detrimental effect for the individual itself (Korringa, 1951; Topsent, 1900) while the sponge does not penetrate the interior of the shell. However, when the hinge and/or the insertion point of the adductor muscle is affected, the correct functioning of the shell's opening/ closing mechanism may be impaired. As a consequence, mortality is probably greater among infested oysters which also become more susceptible to predation (Thomas, 1979; Pomponi \& Meritt, 1990). In some situations, the attack extends to the whole shell causing it to become brittle. When the inner surface of the shell is affected, the oyster starts to produce conchyolin to cover the holes, giving rise to an additional metabolic charge (Topsent, 1900; Korringa, 1951; Wells, 1959). As a result, the inner surface of the shell shows small protuberances and dark spots.

These negative impacts of the excavating sponges on oysters may be of particular relevance in low-density oyster populations as those of the Blanes littoral coast. In addition to the relative low-density that characterizes oyster populations in the oligotrophic Mediterranean waters, those at the studied area support indeed a strong fishing pressure.

The aims of the present study were: (i) to identify the species of excavating sponges infesting oysters at the studied site; (ii) to estimate the degree of implantation of sponges in oyster shells; (iii) to evaluate sponge impact on the natural oyster populations; and (iv) to detect the possible detrimental effect of the sponges on the host.

\section{MATERIALS AND METHODS}

A total of 29 oysters (Ostrea edulis L.), ranging from 3.5 to $10 \mathrm{~cm}$ in height (mean $6.5 \mathrm{~cm}$ ), were collected from depths between 0.5 and $4 \mathrm{~m}$ from the littoral zone of Blanes (Catalan coast, north-western Mediterranean, $41^{\circ} 40.12^{\prime} \mathrm{N} 02^{\circ} 47.10^{\prime} \mathrm{E}$ ) during July and August 1986. Three stations with a priori different degrees of substrate inclinations were chosen: Station 1, on a horizontal surface at depths between 2 and $4 \mathrm{~m}$; Station 2, on a north-east subhorizontal surface at a depth of $2 \mathrm{~m}$; and Station 3, on a vertical surface at depths between 0.5 and $3 \mathrm{~m}$.

First, the excavating sponges were taxonomically identified. After completely removing epibionts from the shells, dry weights $\left(120^{\circ} \mathrm{C}, 24 \mathrm{~h}\right)$ were calculated for each valve separately and for the soft body. Total oyster weight was defined as the sum of these three weights. Then, the total outer shell area (i.e. the sum of the outer surface 
areas of both upper and lower valves) and the area of the inner surface (only for the excavated valves) were also estimated. Because of the difficulty in calculating the area occupied by the sponge inside the shell, we calculated the degree of oyster infestation as the percentage of surface area occupied by the externally visible parts of the sponge (i.e. papillae at the outer side of the valve and black spots at the inner side of the valve) of each valve surface (infestation area) to the total area of the corresponding valve surface (Pomponi \& Meritt, 1990). The outlines of each surface were obtained by covering each valve with transparent polyethylene on which the outer limits were drawn. Outlines were later used to estimate areas using a digitizer tablet (Genitizer GT-1212B). The effect of sampling station and valve surface (outer and inner) on the degree of infestation was analysed by twoway analysis of variance (ANOVA).

As losses of $\mathrm{CaCO}_{3}$ due to the excavating activity of sponges may influence shell weight, size-class distributions were estimated on the basis of valve areas. Differences in the average percentage of infested area within size-classes were then assessed by one-way ANOVA.

Three zones of the valve were distinguished in order to describe the infestation accurately and to evaluate its possible effects on the oyster survival: the insertion of the adductor muscle, the area around the hinge and an intermediate region. Differences in the presence of sponge papillae or black spots at each zone and between surfaces were then analysed using one-way ANOVA and Student $t$-test, respectively.

The effect of sampling station on oyster size (either as total weight or total outer area) was assessed by a oneway ANOVA. The relationships between the different parameters considered at the different sampling stations were compared by analysis of covariance (ANCOVA).

It was suspected that the size of the infested area at the inner surface of the valve may be related to the size of the infested area at the outer surface and that this relationship could depend on oyster size (thickness). This dependence was analysed by calculating the correlation between the quotient inner/outer infested areas and oyster size (Pearson correlation analysis).
Assumptions of normality and homoscedasticity, required for parametric analysis, were met either by raw data or appropriate transformations (oyster sizes were log-transformed). These assumptions were checked using Kolmogorov-Smirnov test (Lilliefors probability) and Bartlett test, respectively. Tukey honest significant difference multiple comparisons test were used to assess the groups responsible for the significant effects obtained in the different ANOVA models. All analyses were carried out using Systat (v. 5.2, C SYSTAT Inc., 1990) and SigmaStat (v. 1.0, C 1992-1994 Jandel Corporation) statistical packages.

\section{RESULTS}

All the oysters collected were infested by the excavating sponges Cliona viridis (Schmidt) and Cliona celata Grant, the former being more abundant than the latter. Galleries exclusively affected the lower valve (i.e. that which is directly in contact with the substrate). Both the inner and outer surfaces of this valve showed traces of infestation in all studied oysters.

The percentage of infested area at the lower valve did not significantly differ between sampling sites nor between valve surfaces (two-way ANOVA) (Figure 1A). This percentage did not vary with oyster size-classes (one-way ANOVA) (Figure 2A,B). However, most oysters showed distinct areas of infestation when the inner and outer surfaces of the valve were individually compared. In $55.2 \%$ of the oysters the area was larger at the outer surface, whereas in a $31 \%$ it was larger at the inner surface. Only in $13.8 \%$ of the oysters both surfaces showed similar areas of infestation.

The incidence of the infestation was similar at the three zones of the valve (i.e. insertion of adductor muscle, hinge and intermediate) and between valve surfaces at each zone (Student $t$-test).

Total oyster weight (TW) and total outer shell area (TA) differed significantly between sites (ANOVA: TW, $F=3.51, \quad P<0.05$; TA, $F=11.15, P<0.001$ ) (Figure 1B). A Tukey test indicated that the oyster population at site 3 was responsible for the significant effect for both
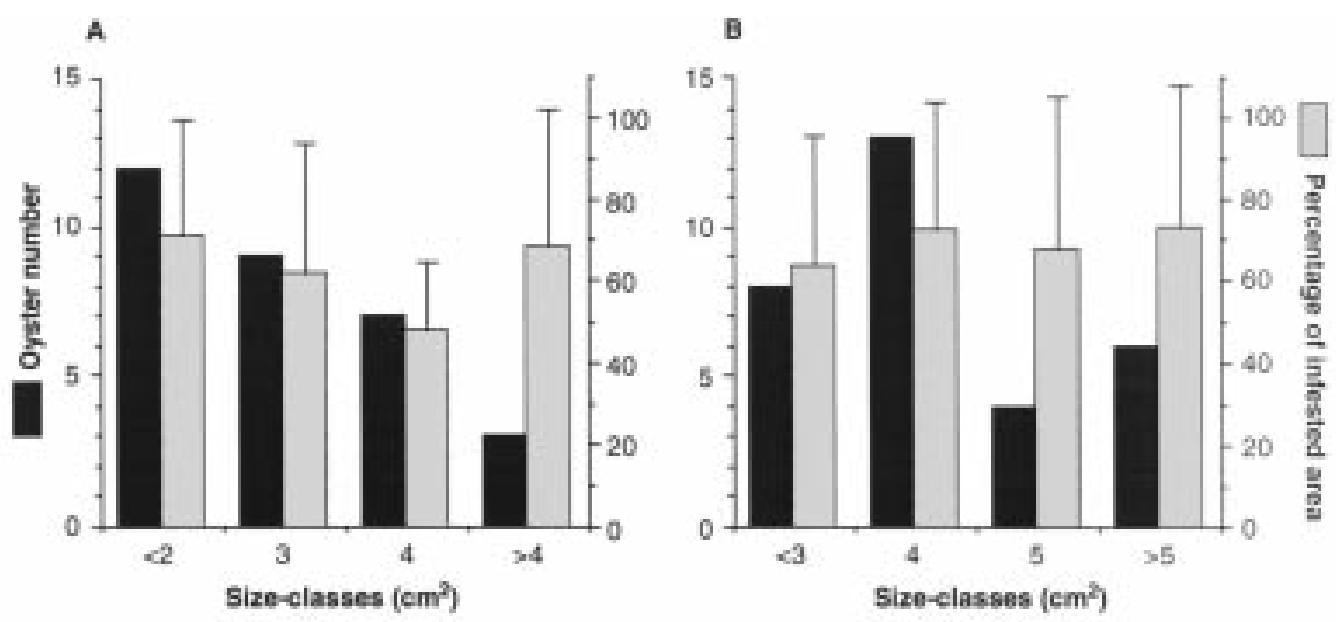

Figure 1. (A) Average percentage of infested area for the inner, outer and total surfaces of the lower valve at the three sites under study; (B) average values of total oyster weight and total oyster area at the three sites under study. Vertical bars indicate standard deviations. 

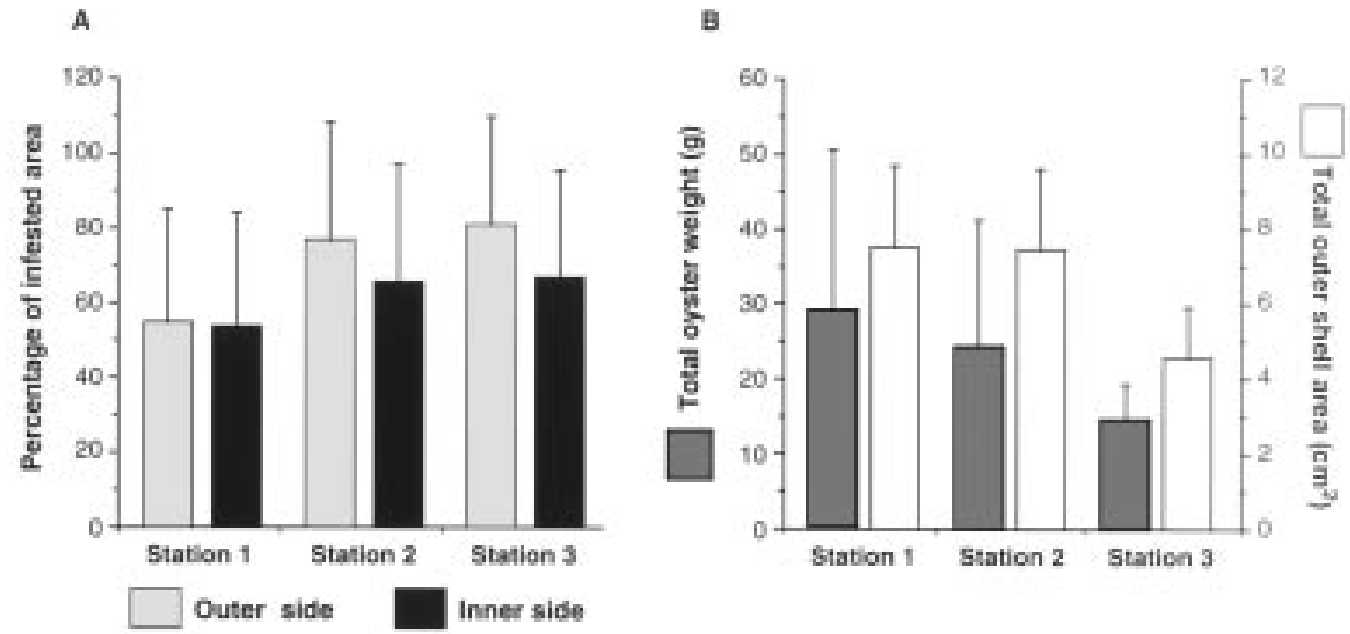

Figure 2. Average percentages of infested area at the different size-classes defined for the lower valve of the oysters: (A) outer surface; (B) inner surface. Vertical bars indicate standard deviations.
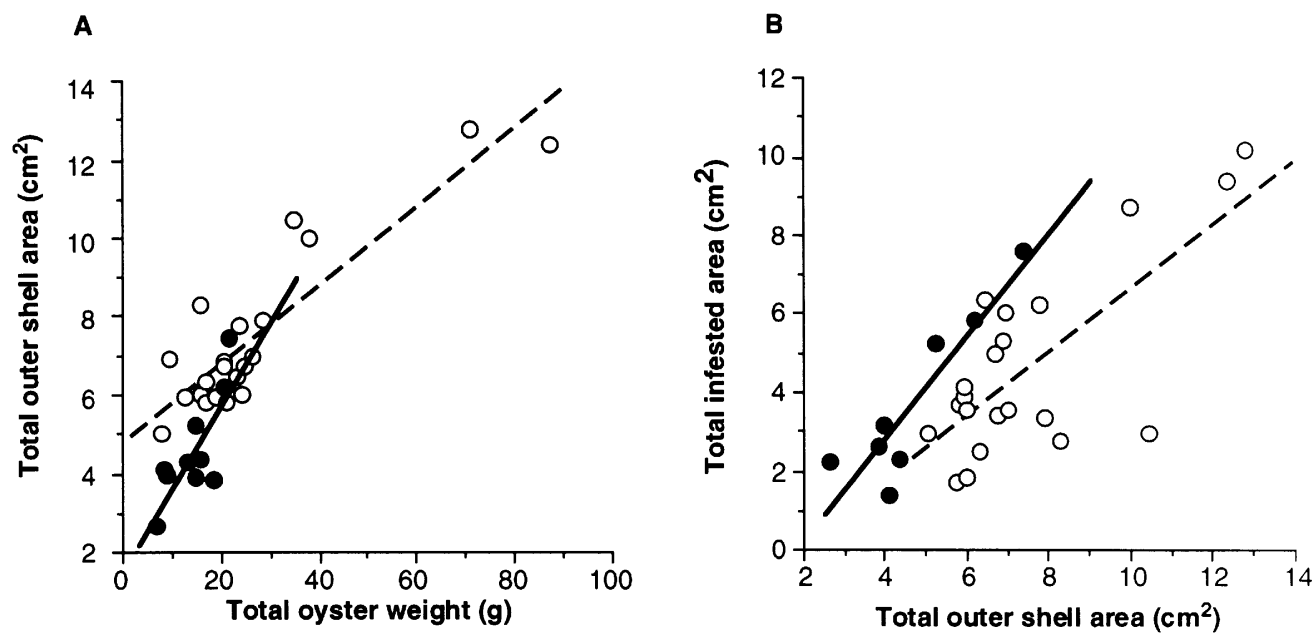

c

D
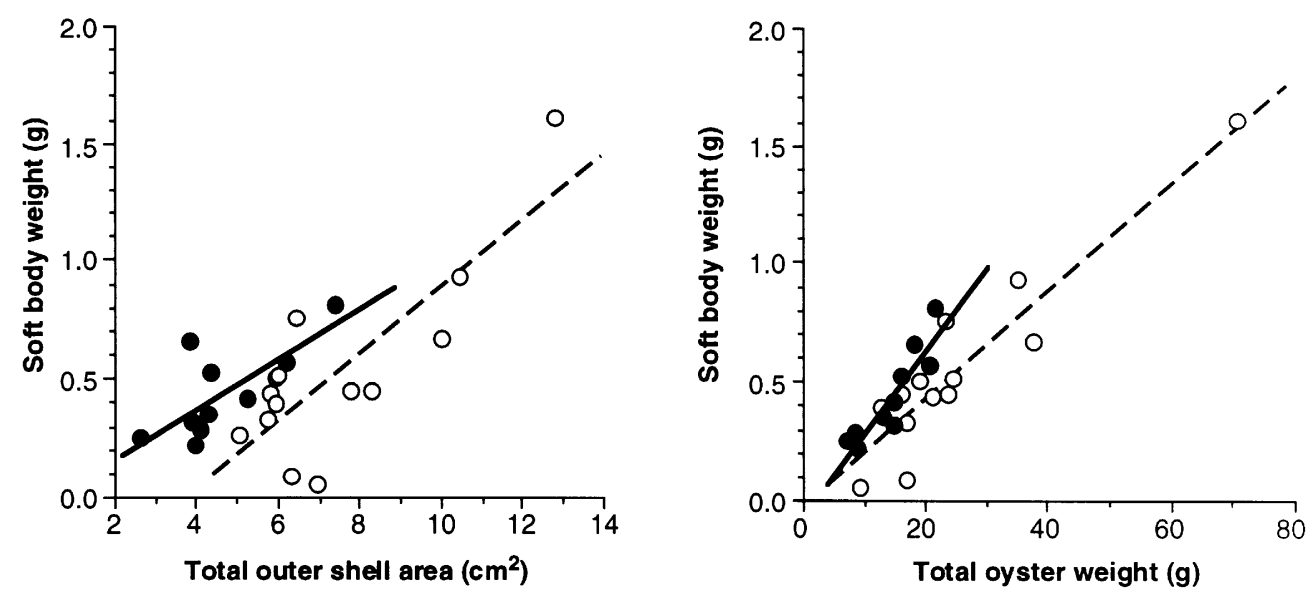

Figure 3. Regression lines showing the relationships between the different parameters estimated from the infested oysters; samples from station 3; $\bigcirc$, samples from stations 1 and 2.

parameters (TW, $P<0.05$; TA, $P<0.001$ ). Therefore, samples from sites 1 and 2 were pooled together for further analyses.

Total outer shell area (TA) was significantly and positively correlated with the following oyster parameters: total oyster weight (TW), total infested area (IA-T), and soft-body weight (BW). These relationships were fitted to different regression functions for the two groups of sampling stations (Figure $3 \mathrm{~A}-\mathrm{C}$ ), the obtained lines having significantly different slopes (ANCOVA; TW, 
Table 1. Percentage of bivalve shells infested (\% BSI) by excavating sponges in different geographic zones (completed from Barthel et al., 1994).

\begin{tabular}{|c|c|c|c|c|}
\hline Author & Location & Sponges & Bivalves & $\%$ BSI \\
\hline Old, 1941 & Chesapeake Bay (north-west Atlantic) & Pione truitti & Crassostrea virginica & $25-75$ \\
\hline Hopkins, 1956 & $\begin{array}{l}\text { South Carolina } \\
\text { (north-west Atlantic) }\end{array}$ & $\begin{array}{l}\text { Pione vastifica, Pione truitti, } \\
\text { Cliona lobata, Cliona celata }\end{array}$ & $\begin{array}{l}\text { Oysters (no species } \\
\text { name given) }\end{array}$ & $15-100$ \\
\hline Hartman, 1958 & $\begin{array}{l}\text { southern New England } \\
\text { (north-west Atlantic) }\end{array}$ & Cliona spp. & Crassostrea virginica & $80-90$ \\
\hline Wells, 1959 & $\begin{array}{l}\text { Newport River } \\
\quad(\text { north-west Atlantic) }\end{array}$ & Cliona spp. & $\begin{array}{l}\text { Crassostrea virginica, } \\
\text { Ostrea equestris }\end{array}$ & 10.4 \\
\hline $\begin{array}{l}\text { Algarswami \& } \\
\text { Chellam, } 1976\end{array}$ & Indian Ocean & Cliona celata & Pinctada fucata & 20.7 \\
\hline Comley, 1978 & Scotland (north-east Atlantic) & Cliona celata & Modiolus modiolus & 36 \\
\hline Thomas, 1979 & Indian Ocean & Pione vastifica, Cliona celata & Pinctada fucata & 8.5 \\
\hline $\begin{array}{l}\text { Krakatitsa \& } \\
\text { Kaminskaya, } 1979\end{array}$ & Black Sea & Pione vastifica & Ostrea edulis & $23-47.6$ \\
\hline Pomponi \& Meritt, 1990 & Chesapeake Bay (north-west Atlantic) & Pione truitti & Crassostrea virginica & 90 \\
\hline Barthel et al., 1994 & subarctic Balsfjord (northern Norway) & Pione vastifica & Chlamys islandica & $83-88$ \\
\hline Present work & north-west Mediterranean & Cliona viridis, Cliona celata & Ostrea edulis & 100 \\
\hline
\end{tabular}

$F=22.23, \quad P<0.001 ; \quad$ IA-T $, \quad F=25.09, \quad P<0.001 ; \quad$ BW, $F=16.36, P<0.001)$ :

Stations 1 and 2:

$\mathrm{TA}=1592.44+208.75 * \mathrm{TW}, r^{2}=0.61, P=12.26, P<0.01$

$\mathrm{IA}-\mathrm{T}=-2381.75+1.31 * \mathrm{TA}, r^{2}=0.83, P=28.27, P<0.002$

$\mathrm{BW}=-0.0445+0.0001 * \mathrm{TA}, r^{2}=0.55, P=9.7, P<0.02$

Station 3:

$\mathrm{TA}=4792.15+100.72 * \mathrm{TW}, r^{2}=0.79, P=71.66, P<0.0001$

$\mathrm{IA}-\mathrm{T}=-1417.17+0.81 * \mathrm{TA}, r^{2}=0.53, P=21.08, P<0.001$

$\mathrm{BW}=-0.4520+0.0001 * \mathrm{TA}, r^{2}=0.59, P=18.83, P<0.001$

A positive correlation was also found between BW and TW. These parameters also followed different regression functions for each group of samples (Figure 3D), the obtained lines having significantly different slopes (ANCOVA, $F=31.85, P<0.001$ ).

Stations 1 and 2: BW $=-0.0602+0.0347 * \mathrm{TW}, r^{2}=0.83$, $F=38.07, P<0.001$

Station 3: $\mathrm{BW}=0.0200+0.0225 * \mathrm{TW}, r^{2}=0.80, F=53.24$, $P<0.001$

The soft-body weight was not significantly correlated with the outer and inner infested areas. The quotient inner/outer infested areas was not significantly correlated to the shell size parameters (total oyster weight and total outer shell area).

\section{DISCUSSION}

The results provide evidence that the studied oysters belonged to two different populations, their differences being expressed by the studied parameters as well as by the following relationships: (1) total outer shell area vs total oyster weight; (2) soft-body weight vs total oyster size; and (3) total infested area vs total outer shell area. Site 3, which proved to be significantly different from the remaining two sites, was located on a vertical wall. However, both populations showed similar results regarding the degree of infestation and the factors that may condition it (e.g. shell thickness and available surface).

The percentage of infestation recorded in the oyster populations under study $(100 \%)$ is higher than those recorded for other bivalves from north-western Atlantic or Indian coasts (Table 1). Cliona viridis was found in almost all the studied oysters. Although considered a cosmopolitan species, it is not usually reported excavating bivalve shells in other geographical areas. Of the bivalve shells collected in the photic zone of the south-west coast of Scotland $90 \%$ were attacked by excavating or boring organisms confined to this photic zone (e.g. algae and some limpets) (Akpan \& Farrow, 1985). This situation closely resembles our observation in that, although C. viridis is not strictly confined to the photic zone, it may be considered to some degree to be light dependent due to the possession of zooxanthellae symbionts. Then shallow waters can be considered an optimal habitat for this species (Rosell \& Uriz, 1991).

The infestation by clionid species, despite affecting extensively oysters, is not sufficient to prevent the normal development of oyster populations. The establishment of a subtle balance between the two partners: the sponge and the mollusc, has been suggested in the case of the bivalve Chlamys islandica (Müller) infested by the excavating sponge Pione vastifica (Hancock) (formerly in Cliona; see Rosell \& Uriz, 1997) (Barthel et al., 1994). Nevertheless, in Chlamys islandica less than $65 \mathrm{~mm}$ shell height, 90\% of the scallops had negligible infestation (Barthel et al., 1994) while the infestation of Ostrea edulis by Cliona viridis seems to affect equally all sizes of oysters.

No correlation was found between the outer and inner infested areas of the shells, nor between the inner infested area and shell size. Moreover, although low values of the quotient inner/outer infested areas were expected for large shells (thicker shells) and high values were expected for the smaller shells (thinner shells), the results indicated that the shell thickness did not influence the relationship between both areas. In light of our data, we suggest that colonization by the excavating sponges could occur early in the oysters' life cycle. Subsequently, they are able to 
occupy all the available surface at the lower valve. Investigations on Pione truitti (Old) (formerly in Cliona; Rosell \& Uriz, 1997) excavating in Crassostrea virginica showed that the percentage of shell weakened by the sponge was roughly similar when two different oyster size-classes were compared (Pomponi \& Meritt, 1990), this supporting our observations.

It would be difficult, and beyond the scope of the present study, to measure the extend to which infestation by excavating sponges, particularly when excavations reach the inner surface of the valve, would increase the metabolic costs for the infested oysters, and cause their growth rates to slow down. The absence in the studied area of oysters having the inner surfaces of their valves free of excavations prevented us from estimating the relationship between size and biomass of 'healthy' oysters. In any case, the possible metabolic costs due to the infestation seems to be so low that it did not obscure the relationships between oyster soft-body weight and either total oyster weight or total outer surface area. Accordingly, Barthel et al. (1994) did not found significant changes in the relation of tissue weight to shell size in heavily infested specimens of Chlamys islandica as compared to only lightly infested specimens.

These excavating sponges are able to effectively colonize the scarce calcareous substrate available, at least for the first few metres depth. Colonization by sponges could occur either by direct contact or dispersion of sexual (larvae) and asexual (gemmules or buds) reproductive elements (Warburton, 1958; Thomas, 1979; Rosell, 1993, 1996). The granite nature of the basal substrate of the oyster habitat does not seem to favour colonization by contact. However, as these sponges take advantage of the thin aggregates of calcareous algae covering the granite substrate in the studied area (i.e. from 0 to $5 \mathrm{~m}$ in depth), colonization by contact appeared to be feasible. This method of propagation implies that oyster shells are colonized by 'adult' sponges and would explain the rapid sponge growth relative to oyster growth.

Cliona viridis and Cliona celata are the most abundant and widespread excavating sponge species in the Mediterranean Sea, although C.celata is less abundant in the shallow waters off Blanes littoral zone than in deeper waters (100-110 m) (Rosell, 1996). Other widespread, but less abundant species, such as Pione vastifica, which were also present excavating calcareous algae at the studied zone, were not found living in the examined oysters. Consequently, in light of our data, C. viridis and C. celata emerged as the single excavating species able to effectively compete with other non-excavating or excavating organisms when trying to colonize the particular calcareous substrate provided by oyster shells in the photic zone of the north-western Mediterranean littoral zone.

We are very grateful to J. Boronat and P. Surís who collected the oysters and helped us with the laboratory work. This study has been funded by a fellowship from 'La Caixa' and the 'Consejo Superior de Investigaciones Científicas' (CSIC) of Spain enclosed in the research project: 'Un modelo de organización del bentos litoral mediterráneo'. Subsequent funds were provided by the projects DGCICYT PB94-0015, CICYT MAR95-1764 and the government of Catalonia (1995 SGR-00443 and 1997 SRG00084).

\section{REFERENCES}

Akpan, E.B. \& Farrow, G.E., 1985. Shell bioerosion in highlatitude low-energy environments: Firths of Clyde and Lorne, Scotland. Marine Geology, 67, 139-150.

Algarswami, K. \& Chellam, A., 1976. On fouling and boring organisms and mortality of pearl oysters in the farm at Veppalodai, Gulf of Mannar. Indian Journal of Fisheries, 23, $10-22$.

Barthel, D., Sundet, J. \& Barthel, K.-G., 1994. The boring sponge Cliona vastifica in a subarctic population of Chlamys islandica. An example of balanced commensalism? In Sponges in time and space (ed. R.W.M. van Soest et al.), pp. 289-296. Rotterdam: A.A. Balkema.

Comley, C.A., 1978. Modiolus modiolus (L.) from the Scottish West Coast. I. Biology. Ophelia, 17, 167-193.

Hartman, W.D., 1958. Natural history of the marine sponges of southern New England. Bulletin of the Peabody Museum of Natural History, 12, 1-155.

Hopkins, S.H., 1956. The boring sponges which attack South Carolina oysters, with notes on some associated organisms. Contributions of the Bears Bluff Laboratory, 23, 1-30.

Korringa, P., 1951. The shell of Ostrea edulis as a habitat. Archives der Néerlandoise de Zoologie, 10, 32-152.

Krakatitsa, T.F. \& Kaminskaya, L.D., 1979. Boring activity of sponges-pests of Black Sea oyster beds. Biologia Morya. Vladivostock, 6, 15-20.

Old, M.C., 1941. The taxonomy and distribution of the boring sponges (Clionidae) along the Atlantic coast of North America. Publications of the Chesapeake Biological Laboratory, 44, $1-30$.

Pomponi, S.A. \& Meritt, D.W., 1990. Distribution and life history of the boring sponge Cliona truitti in the Upper Chesapeake Bay. In New perspectives in sponge biology (ed. K. Rützler), pp. 384-390. Washington, DC: Smithsonian Institution Press.

Rosell, D., 1993. Effects of reproduction in Cliona viridis (Hadromerida) on zooxanthellae. Scientia Marina, 57, 405-413.

Rosell, D., 1996. Systematics, biology and ecology of the Mediterranean excavating sponges. $\mathrm{PhD}$ thesis, Universitat de Barcelona, Barcelona, Spain.

Rosell, D. \& Uriz, M.J., 1991. Cliona viridis (Schmidt, 1862) and Cliona nigricans (Schmidt, 1862) (Porifera, Hadromerida): evidence which shows they are the same species. Ophelia, 33, $45-53$.

Rosell, D. \& Uriz, M.J., 1997. Phylogenetic relationships within the excavating Hadromerida (Porifera), with a systematic revision. Cladistics, 13, 349-366.

Thomas, P.A., 1979. Boring sponges destructive to economically important molluscan beds and coral reefs in Indian seas. Indian Fournal of Fisheries, 26, 163-200.

Topsent, E., 1900. Étude monographique des spongiaires de France. III. Monaxonida (Hadromerida). Archives de Zoologie Expérimentale et Général, 8, 1-331.

Warburton, F.E., 1958. Control of the boring sponge on oyster beds. Progress Reports of the Atlantic Coast Stations of the Fisheries Research Board of Canada, 69, 7-11.

Wells, H.W., 1959. Boring sponges (Clionidae) of the Newport River, North Carolina. Fournal of the Elisha Mitchell Scientific Society, 75, 168-173.

Submitted 24 June 1997. Accepted 16 March 1998. 
